\title{
Screening of Bacteria for Their Chlorpyrifos Degrading Ability
}

\author{
Uunati N. Ahir, Trupti K. Vyas*, Bhavik P. Sutaria, Priti R. Faldu and K.G. Patel \\ Food Quality Testing Laboratory, N M College of Agriculture, Navsari Agricultural \\ University, Navsari-396450, Gujarat, India \\ *Corresponding author
}

\begin{abstract}
A B S T R A C T
Chlorpyrifos $(0,0$ - diethyl 0 - $(3,5,6$ - trichloro - 2 - pyridyl phosphorothioate $)$ is broadspectrum pesticide with trade names Dursban, Lorsban and Spannit, displaying insecticidal activity against Lepidoptera, Diptera, Homoptera, Coleoptera, Orthoptera,

\begin{tabular}{|l|}
\hline Ke y w or d s \\
Biodegradation, \\
Chloryyiros, \\
Emulsification activity, \\
Pesticide, \\
Organophosphate \\
\hline Article Info \\
\hline Accepted: \\
04 July 2018 \\
Available Online: \\
10 August 2018 \\
\hline
\end{tabular}
Hymenoptera and Hemiptera. However, these organophosphates pesticides have acute neurotoxicity as they suppress acetylcholine esterase (AChE). Hence, present study deals with exploring bacteria for chlorpyrifos degradation ability. Total 10 different samples were collected from soil where chlorpyrifos pesticide was applied. Out of these 10 samples, six samples showed bacteria which are able to grow on Bushnell and Haas agar containing chlorpyrifos as sole carbon source. 15 bacteria which produce zone of clearance near colony were considered efficient chlorpyrifos degrader and purified for further studies. Screening of the isolate for chlorpyrifos revealed that AUC10 showed higher degradation (95\%), followed by AUC12 (93\%) and AUC11 (90\%). Ability of isolates to emulsify hydrophobic molecules revealed that higher emulsification activity was found in groundnut oil followed by coconut oil and cotton seed oil. Morphological characterization revealed that out of 15 isolates 6 bacteria were Gram positive whereas 9 isolates were Gram negative. Thus, isolate AUC10 possessed higher chlorpyrifos degradation rate compared to other isolated bacteria and can be used for bioremediation of chlorpyrifos contaminated sites.
\end{abstract}

\section{Introduction}

India is agriculture based country and about $60-70 \%$ of its population is dependent on agriculture. However, due to industrialization and urban encroachment agriculture land area is rapidly decreasing. On the other hand, overpopulation demands more food and agricultural produce. Pesticides were introduced to agriculture to fulfil the increased food needs of the growing global population. Hence agrochemicals like insecticides, fungicides, pesticides, and herbicides are used on a large scale in agricultural lands to mitigate lose due to pathogens and insect/pest. About $30 \%$ of agricultural produce is lost due to pests and insects. Hence, the use of pesticides has become indispensable in agriculture (Kavikarunya and Reetha, 2010).

Application of pesticide becomes an evil due to its persistent nature (Zaki et al., 1982; Gavrilescu, 2005; Tariq et al., 2007). Pesticide residues remain in environment for longer 
period and biomagnifying at different level of food chain. Due to the long persistence of organochlorines (lindane, heptachlor, dichlorodiphenyltrichloroethane (DDT), etc.) and their tendency to bioaccumulation and their potential toxicity towards non-target organisms, this group of pesticide has been replaced by relatively less persistent and yet effective organophosphorus (OP) compounds. Organophosphates pesticides degrade faster than the organochlorines pesticides, but this class of pesticide has acute neurotoxicity as they suppress acetylcholine esterase (AChE). Acetylcholine esterase regulates the enzyme of neuro transmitter by reducing acetylcholine concentration at synaptic junction. When AChE is inactivated, e.g., by an organophosphate pesticide, the concentration of acetylcholine in the junction remains high and continuous stimulation of the muscle or nerve fiber occurs, resulting eventually in exhaustion and tetany.

Chlorpyrifos $(0,0$ - diethyl 0 - $(3,5,6-$ trichloro -2 - pyridyl phosphorothioate) is important in agriculture in light of restricted or banned usage of organochlorine compounds. It is a broadspectrum pesticide with trade names Dursban, Lorsban and Spannit, displaying insecticidal activity against a wide range of insect and arthropod pests (Cho et al., 2002). It produces contact toxicity against insect Lepidoptera, Diptera, Homoptera, Coleoptera, Orthoptera, Hymenoptera and Hemiptera (Gray, 1965) and also against arachnids as spiders, mites and ticks (Kenaga et al., 1965). Hence, present study aims to explore chlorpyrifos degrading bacteria.

\section{Materials and Methods}

\section{Soil sample collection}

To isolate chlorpyrifos degrading microbes, soil samples were collected from chlorpyrifos contaminated soil or farm soil where chlorpyrifos was applied. Total 10 different soil samples were collected, out of which eight samples were taken from vegetable (okra, brinjal, spine gourd and pointed gourd) farm of ASPEE college of Horticulture and Forestry, Navsari Agricultural University, Navsari, India. Two samples were collected from soil where chlorpyrifos was applied on mango orchard at Navsari Agricultural University, Navsari. Samples were collected in sterile glass bottle and processed for further isolation within $6 \mathrm{hrs}$ of collection.

\section{Enrichment of soil samples}

Soil samples collected from different farm were used for isolation of chlorpyrifos degrading bacteria by enrichment technique.

For enrichment of samples, Bushnell and Haas Media (BHM) (Bushnell and Haas, 1941) containing gm/l Magnesium sulphate-0.20; Calcium chloride-0.02; Monopotassium phosphate-1; Dipotassium phosphate-1; Ammonium nitrate-1; Ferric chloride-0.05) was prepared and sterilized. $1 \mathrm{gm}$ of each soil sample was separately added in $50 \mathrm{ml}$ BHM broth containing $1 \mu \mathrm{g} / \mathrm{ml}$ chlorpyrifos as sole carbon source. Flasks were incubated at room temperature for 15 days.

\section{Isolation of bacteria}

After 15 days of incubation, bacteria were isolated from enrichment samples. Each sample was diluted up to $10^{-6}$ dilution by serial dilution technique. $100 \mu \mathrm{l}$ of sample from each dilution was spread on Bushnell and Haas agar (BHM) plates containing $1 \mu \mathrm{g} / \mathrm{ml}$ chlorpyrifos. Plates were incubated at room temperature for $48-72 \mathrm{hrs}$ and observed for colony formation. Total colony forming units were calculated and expressed as cfu/g. Cells grown on BHM were isolated and further purify. Purified samples were grown on nutrient agar slant and stored at $4{ }^{\circ} \mathrm{C}$ until use. 


\section{Screening of bacteria}

To find out potential isolate, all the isolated bacteria were screened for their efficacy to degrade chlorpyrifos. For determination of degradation potential of isolated bacteria were separately inoculated in BHM broth supplemented with $1 \mu \mathrm{g} / \mathrm{ml}$ chlorpyrifos as sole carbon source and incubated at room temperature on shaker at $120 \mathrm{rpm}$ for 7 days.

After 7 days incubation growth rate measure at $600 \mathrm{~nm}$ on spectrophotometer (Vyas and Murthy, 2015) and chlorpyrifos degradation was measured by the method described by Venugopal et al., (2013). After measurement of growth from test samples, cells were removed by centrifugation and supernatant was used for chlorpyrifos estimation.

To estimate chlorpyrifos, first aniline was diazotize and used for experiment. Briefly, 2 $\mathrm{gm}$ of aniline was dissolved in $100 \mathrm{ml}$ Round Bottomed Flask (RBF) contained $5.5 \mathrm{ml}$ of concentrated $\mathrm{HCl}$ and $5.5 \mathrm{ml}$ of distilled water. RBF was placed in ice bucket so that temperature of reaction remains below $5^{\circ} \mathrm{C}$. Now $1.6 \mathrm{~g}$ of sodium nitrite was dissolved in $7.5 \mathrm{ml}$ of pre-chilled water and tube was kept in ice bucket.

Both the solution i.e., aniline and sodium nitrite was mixed resulting in formation of benzene diazonium chloride solution. For quantification, $1 \mathrm{ml} 2 \mathrm{M} \mathrm{NaOH}$ solution was added in $25 \mathrm{ml}$ volumetric flask contain( 0.1 to $1 \mu \mathrm{g} / \mathrm{ml}$ ) test sample and incubated for $30 \mathrm{~min}$. $0.5 \mathrm{ml}$ of diazotized aniline as prepared above was added and further incubated for $10 \mathrm{~min}$.

Color developed was measured at $490 \mathrm{~nm}$ against reagent blank. Standard graph of chlorpyrifos was prepared using standard chlorpyrifos (Sigma-Aldrich) and concentration of test samples was extrapolated from standard graph.

\section{Emulsification activity (E24)}

Cells were inoculated in mineral salt medium supplemented with $1 \mu \mathrm{g} / \mathrm{ml}$ chlorpyrifos and incubated at their optimum temperature for 7 days on rotary shaker at $150 \mathrm{rpm}$. Emulsification activity was measured as emulsification index $-\mathrm{E}_{24}$ (Cooper and Goldenberg, 1987). In $2 \mathrm{ml}$ of culture supernatant (after extraction chlorpyrifos), 2 $\mathrm{ml}$ of kerosene, cotton seed oil, ground nut oil, coconut oil was added and mixed vigorously for 2 minutes. This was allowed to stand for $24 \mathrm{hrs}$. After 24 hrs, emulsification activity was measured as:

Height of emulsion layer Emulsification Index (E24) = X 100

Height of liquid column

\section{Morphological characterization}

Potential isolates which showed higher chlorpyrifos degradation were selected for further studies and identified by morphological characterization. Morphological characterization was done by colony characteristic and Gram's reaction. For colony characteristics, isolate was grown on nutrient agar and incubated at room temperature for $24 \mathrm{hrs}$. The morphological features such as size, shape, texture, opacity, colour, elevation, form, margin, etc. were recorded. Gram staining of the isolate was performed and observed under oil immersion lens for its morphology and Gram's reaction.

\section{Results and Discussion}

\section{Soil sample collected}

To isolate chlorpyrifos degrading microbes, soil samples were collected from chlorpyrifos contaminated soil or farm soil where chlorpyrifos was applied. Total 10 different soil samples were collected, out of which eight 
samples were collected from various farm like two from okra, two from brinjal, two from pointed guard, two from spine guard of ASPEE college of Horticulture and Forestry, Navsari Agricultural University, Navsari, India. Two samples were collected from soil where chlorpyrifos was applied on mango orchard.

\section{Enrichment of soil samples}

For enrichment of chlorpyrifos degrading bacteria, samples were enriched in BHM supplemented with chlorpyrifos. Flasks were incubated for 15 days. After 4 days of incubation a little turbidity was observed in media indicating growth of bacteria. After 15 days of incubation there bacteria were isolated and purify.

\section{Isolation of bacteria}

After 15 days of incubation, bacteria were isolated from enrichment samples. Enriched samples were serially diluted and bacteria were isolated by standard plate count method using BHM agar containing $1 \mu \mathrm{g} / \mathrm{ml}$ chlorpyrifos.

Out 10 enriched samples, growth was observed in six samples only. Enumeration results showed that soil sample collected from brinjal plot contained $2 \times 10^{4} \mathrm{cfu} / \mathrm{g}$ and $1.5 \times$ $10^{4} \mathrm{cfu} / \mathrm{g}$ respectively of two different samples. Soil sample collected from okra plot contained $1.5 \times 10^{3} \mathrm{cfu} / \mathrm{g}$ whereas, soil sample collected from pointed guard contained $7 \times$ $10^{3} \mathrm{cfu} / \mathrm{g}$. Soil sample collected from spine guard and mango farm contained $4.6 \times 10^{4}$ $\mathrm{cfu} / \mathrm{g}$ and $2.15 \times 10^{4} \mathrm{cfu} / \mathrm{g}$. Total 15 bacterial isolates were able to show zone of clearance near colony. These 15 isolates were designated as AUC1 to AUC15. Total 15 different bacteria were isolated from six different samples which produced clear zone near colony (Table 1).

\section{Screening by spectroscopic assay}

All the 15 isolates were quantitatively screened for their ability to degrade chlorpyrifos. For quantitative screening, cells were grown in BHM supplemented with chlorpyrifos for 7 days. Residual chlorpyrifos was extracted and \% degradation was determined. Out of all the isolates, AUC10 showed higher degradation i.e., $95 \%$ followed by AUC12 (93\%) and AUC11 (90\%) (Figure 1). Least degradation $35 \%$ was observed in AUC13 (Figure 1). Growth was also monitored with degradation rate. Higher growth was observed in AUC11 (0.484), followed by AUC10 (0.45) and AUC12 (0.315) (Figure 1). Least growth was observed in ACU1 (0.042).

\section{Screening based on emulsification activity}

Isolates were examined for their ability to emulsify different hydrophobic compounds. Hence, they were tested for their ability to emulsify cotton seed oil, groundnut oil, kerosene and coconut oil. Out of 4 different hydrophobic molecules used, highest emulsification activity was observed in ground nut oil, followed by coconut oil and cotton seed oil whereas, least was observed in kerosene (Table 2). In ground nut oil, AUC15 showed higher emulsification activity (48\%) followed by AUC1 (43 \%) and AUC7 (36 \%) (Figure 2). Least emulsification activity $12 \%$ was observed in AUC11 and AUC14. Whereas, in coconut oil AUC1 showed higher emulsification activity (36\%) followed by AUC6 (35\%). Least emulsification activity 12 $\%$ was observed in AUC3 (15\%). In cotton seed oil $4 \%$ and in kerosene it 4 to $8 \%$ emulsification activity was observed by all the isolates.

Microbes play a crucial role in degradation of organic molecules and thus play an important role in biogeochemical cycles of carbon. 
Table.1 Enumeration and zone of clearance of various samples

\begin{tabular}{|c|l|c|c|}
\hline Sr. No. & Soil sample & Total Viable Count(cfu/g) & Zone of clearance \\
\hline 1 & Brinjal-1 & $2 \times 10^{4}$ & 4 \\
\hline 2 & Brinjal-2 & $1.5 \times 10^{4}$ & 2 \\
\hline 3 & Okra -1 & $1.5 \times 10^{3}$ & 1 \\
\hline 4 & Okra -2 & - & - \\
\hline 5 & Pointed guard-1 & $7 \times 10^{3}$ & 4 \\
\hline 6 & Pointed guard-2 & - & - \\
\hline 7 & Spine guard-1 & - & 2 \\
\hline 8 & Spine guard-2 & $4.6 \times 10^{4}$ & 2 \\
\hline 9 & Mango-1 & $2.15 \times 10^{4}$ & - \\
\hline 10 & Mango-2 & - & - \\
\hline
\end{tabular}

Table.2 Emulsification activity (\%) of various hydrophobic molecules by AUC1 - AUC15

\begin{tabular}{|c|c|c|c|c|c|}
\hline $\begin{array}{c}\text { Sr. } \\
\text { No. }\end{array}$ & Isolates & $\begin{array}{c}\text { Cotton seed } \\
\text { oil }\end{array}$ & Groundnut oil & Kerosene & Coconut oil \\
\hline $\mathbf{1}$ & AUC1 & 4.0 & 43.0 & 4.0 & 36.00 \\
\hline $\mathbf{2}$ & AUC2 & 8.0 & 32.0 & 4.0 & 32.00 \\
\hline $\mathbf{3}$ & AUC3 & 8.6 & 20.0 & 4.0 & 15.00 \\
\hline $\mathbf{4}$ & AUC4 & 8.6 & 20.0 & 4.0 & 24.00 \\
\hline $\mathbf{5}$ & AUC5 & 4.0 & 24.0 & 4.0 & 16.00 \\
\hline $\mathbf{6}$ & AUC6 & 4.0 & 24.0 & 4.0 & 35.00 \\
\hline $\mathbf{7}$ & AUC7 & 8.0 & 36.0 & 4.0 & 27.70 \\
\hline $\mathbf{8}$ & AUC8 & 4.0 & 28.0 & 4.3 & 25.00 \\
\hline $\mathbf{9}$ & AUC9 & 4.0 & 28.0 & 4.0 & 32.00 \\
\hline $\mathbf{1 0}$ & AUC10 & 8.0 & 20.0 & 8.0 & 22.22 \\
\hline $\mathbf{1 1}$ & AUC11 & 8.0 & 12.0 & 4.0 & 26.68 \\
\hline $\mathbf{1 2}$ & AUC12 & 4.0 & 28.0 & 0.0 & 32.00 \\
\hline $\mathbf{1 3}$ & AUC13 & 4.0 & 20.0 & 4.0 & 20.00 \\
\hline $\mathbf{1 4}$ & AUC14 & 4.0 & 12.0 & 4.0 & 20.00 \\
\hline $\mathbf{1 5}$ & AUC15 & 4.0 & 48.0 & 4.0 & 22.22 \\
\hline
\end{tabular}


Fig.1 Growth and degradation rate (\%) by isolates AUC1 - AUC15

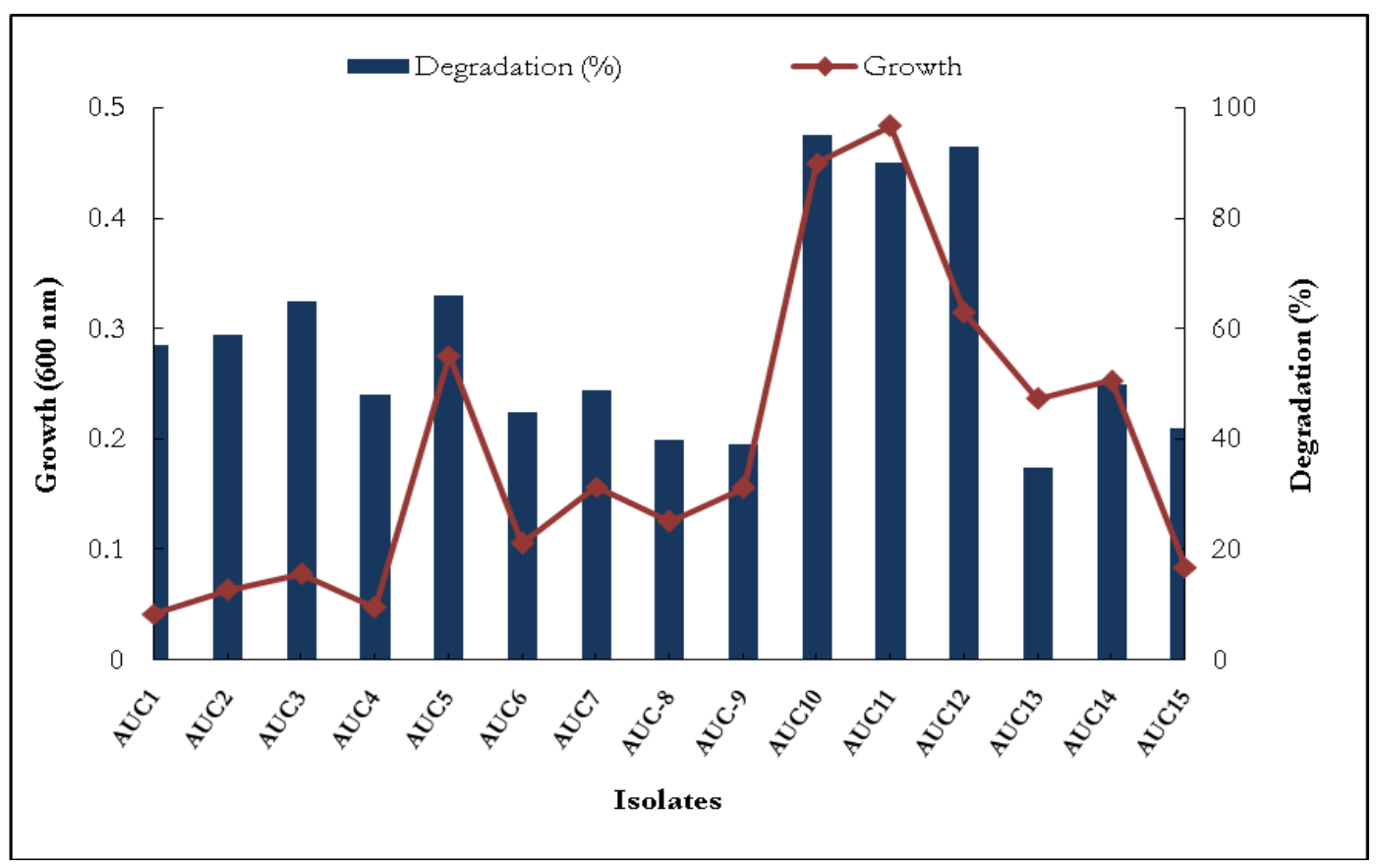

Fig.2 Emulsification activity of bacteria in ground nut oil

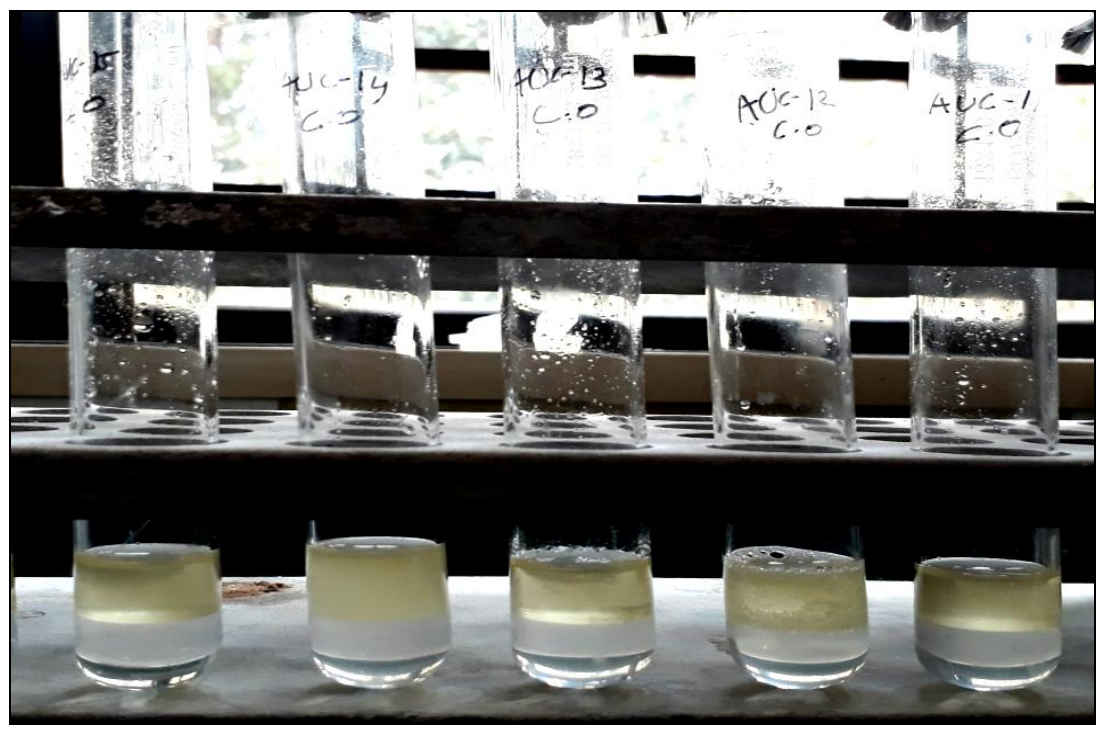

Biodegradation is metabolic ability of microbes to convert complex molecules into monomaniac form or less complex molecules which further integrated into normal metabolic cycles. In present study bacteria were isolated form chlorpyrifos contaminated soil samples and their chlorpyrifos degradation efficacy was evaluated.
For enrichment, collected soil sample was enriched in BHM supplemented with chlorpyrifos as sole carbon source. Kumar et al., (2016) have collected soil samples from chlorpyrifos treated rhizospheric soils of Tomato, Brinjal, Maize and Ground nut. They have enriched samples in MSM containing 50 $\mu \mathrm{g} / \mathrm{ml}$ of chlorpyrifos and incubated at $37^{\circ} \mathrm{C}$ 
on shaker. They have isolated eight bacteria from chlorpyrifos enriched samples and named as CDB-1 to CDB-8. Anwar et al., (2009) have collected soil samples from cotton fields at National Institute of Biotechnology and Genetic Engineering NIBGE, Jhang road, Faisalabad, Pakistan. They have carried out enrichment of pesticide degrading strain from soil sample at 30 and $60 \mathrm{mg} / \mathrm{l}$ chlorpyrifos concentration in MSM medium. They have isolated 11 bacteria from the sample.

Akbar and Sikandar (2015) have collected soil samples from agricultural fields of Jhang and Faisalabad, Punjab, Pakistan. They have carried out enrichment in MSM broth supplemented with $50 \mathrm{mg} / \mathrm{l}$ concentration of chlorpyrifos. They have selected two promising isolates for further studies and identified both the isolates using $16 \mathrm{~S}$ rRNA as Achromobacter xylosoxidans and Ochrobactrum sp.

After enrichment in BHM bacteria were isolated from enrichment samples. Enrichment decreases the microbes unable to use chlorpyrifos as sole carbon source and subsequently increase the number of chlorpyrifos degrading bacteria. Total 15 bacteria were isolated from enrichment sample. Zhao et al., (2012) have collected soil sample from rhizosphere of chives which obtained from Qufu, Shandong Province, China. Chive field site were contaminated with high levels of chlorpyrifos and other organophosphorus pesticides for more than 10 years. They have collected healthy chive plants and the soil adhering to their roots were collected. They have isolated bacteria by by serial dilution method on MSM agar plates, supplemented with 100, 200 and $300 \mathrm{mg} / \mathrm{l}$ of chlorpyrifos as sole source of carbon and energy. Six different strains (D7, D10, D12, D14, D16 and D17) were isolated after enrichment.
Rani et al., (2008) have collected soil sample from agricultural soil of the Chittoor District, Andhra Pradesh, India. Bacteria were isolated on Mineral Salt Medium agar plate containing $50 \mathrm{mg} / \mathrm{l}$ chlorphrifos as sole carbon source. They have isolated four different bacteria from the sample. Yang et al., (2006) isolated an effective chlorpyrifos-degrading bacterium from the sludge of the wastewater treating system of an organophosphorus pesticides manufacturer. They have isolated six bacterial. Among them YC-1 Strain YC-1 was inoculated in flasks containing MSM with100 $\mathrm{mg} / \mathrm{l}$ chlorpyrifos. This Stenotrophomonas sp. YC-1 showed $100 \%$ degradation of chlorpyrifos in 24 hours.

In present study, 10 samples were collected from different sites where chlorpyrifos was applied. Out of these 10 samples, chlorpyrifos degradaing bacteria were isolated from 6 samples. 15 bacterial isolates which showed zone of clearance were selected for further quantitative screening. Out of these AUC10 showed higher degradation rate $(95 \%)$ compared to rest of the isolates. Hence, AUC10 can be effectively used for biodegradation of chlorpyrifos degradation. However, detail further study and its identification is required.

\section{References}

Akbar, S., Sultan, S. 2016. Soil bacteria showing a potential of chlorpyrifos degradation and plant growth enhancement. Brazilian journal of microbiology, 47(3): 563-570.

Anwar, S., Liaquat, F., Khan, Q.M., Khalid, Z.M., Iqbal, S. 2009. Biodegradation of chlorpyrifos and its hydrolysis product 3, 5, 6-trichloro-2-pyridinol by Bacillus pumilus strain, C2A1. Journal of Hazardous Materials, 168(1): 400-405.

Bushnell, L.D., Haas, H.F., 1941. The utilization of certain hydrocarbons by 
microorganisms. Journal of Bacteriology, 41: 653-673.

Cho, C.M., Mulchandani, A., and Chen, W. 2002. Bacterial cell surface display of organophosphorus hydrolase for selective screening of improved hydrolysis of organophosphate nerve agent. Applied Environmental Microbiology, 68: 2026-2030.

Cooper, D.G., and Goldenberg, B.G. 1987. Surface-active agents from two Bacillus species. Applied and environmental microbiology, 53(2): 224-229.

Gavrilescu, M. (2005). Fate of pesticides in the environment and its bioremediation, Engineering in Life Sciences. 5: $497-$ 526.

Gray, H.E. (1965). Dursban a new organophosphorus insecticide. Down to Earth, 21: 2627

Kavi Karunya, S., and Reetha, D. (2012). Biological degradation of chlorpyrifos and monocrotophos by bacterial isolates. International Journal of Pharmaceutical and Biological Archive, 3(3).

Kenaga, E.E., Whitney, W.K., Hardy, J.L., and Doty, A.E. (1965). Laboratory tests with Dursban insecticide. Journal of Economic Entomology, 58: 1043-1050

Kumar, R., Vijaya Gopal, A., Reddy, R.., Durga Rani, V., Triveni, S., and Chari, K. (2016). Molecular diversity of organophosphorus degrading acteria from different field soils. International Journal of Bioresource Science, 3(1): 17.

Rani, M.S., Devi, K.V., Madhuri, R.J., Aruna, S., Jyothi, K., Narasimha, G., and
Venkateswarlu, K. (2008). Isolation and characterization of a chlorpyrifosdegrading bacterium from agricultural soil and its growth response. African Journal of Microbiology Research, 2(2): 26-31.

Tariq, M.I., Afzal, S., Hussian, I., Sultana, N. (2007). Pesticide exposure in Pakistan: a review, Environment International, 33: 1107-1122.

Venugopal, N.V.S., Sumalatha, B., Sainadh, N.V.S. (2013). Determination of Chloropyrifos-A New Approach. Advances in Chemical Science, 2(4): 83-8

Vyas, T.K., Murthy S. R. (2015) Chlorobenzene degradation by Bacillus sp. TAS6CB: A potential candidate to remediate chlorinated hydrocarbon contaminated sites. Journal of basic microbiology, 2015

Yang, C., Liu, N., Guo, X., and Qiao, C. (2006). Cloning of mpd gene from a chlorpyrifos-degrading bacterium and use of this strain in bioremediation of contaminated soil. FEMS Microbiology Letters, 265: 118-125.

Zaki, M.H., Moran, D., Harris, D. (1982). Pesticides in ground water: the aldicarb story in Suffolk country New York. American Journal Public Health 72: 1391-1395.

Zhao, L., Wang, F., and Zhao, J. (2014). Identification and functional characteristics of chlorpyrifos- degrading and plant growth promoting bacterium Acinetobacter calcoaceticus. Journal of basic microbiology, 54(5): 457-463.

\section{How to cite this article:}

Uunati N. Ahir, Trupti K. Vyas, Bhavik P. Sutaria, Priti R. Faldu and Patel, K.G. 2018. Screening of Bacteria for Their Chlorpyrifos Degrading Ability. Int.J.Curr.Microbiol.App.Sci. 7(08): 10-17. doi: https://doi.org/10.20546/ijcmas.2018.708.002 